\title{
The Concept of Liberation in Chitra Banerjee Divakaruni's The Palace of Illusions
}

Ambili M.

Research Scholar

Department of English

Pondicherry University

Pondicherry, India

ambilisanthi@gmail.com

\begin{abstract}
The great Indian Epic Mahabharata celebrates the battle between Pandavas and Kauravas and signifies Draupadi as the fundamental cause of it. Chitra Banerjee Divakaruni unwrapped this belief and made Draupadi a powerful woman with great determination and courage. The Epics all over the world has portrayed woman as pale shadows of men, and men as great warriors. This silence of women has triggered Divakaruni to retell the epic in female voice. Literature always tried to share the changes in society. Unveiling the perfect lady images to the woman, modern female writers made their own literature. This paper goes through the life of an epic woman who has strong cravings of liberation. Also tries to find out whether a female protagonist can undergo inclinations in the life of Male characters who always hold the seal of divine figure, who always live for the warfare.
\end{abstract}

Keywords: Perfect woman, Patriarchy, Feminine, Mahabharatha, Polyandry. 
Mahabharata, the great Indian epic which is both magical and real at the same time, tells the story of the warfare of Pandavas and Kauravas. Draupadi, the wife of Pancha Pandavas, is believed to be the destroyer of the third age of man. Chitra Banerjee Divakaruni, changes this belief and gave a new outlook on Draupadi ( Panchaali ) through the novel, The Palace of Illusions. She depicts Draupadi as a strong woman who has her own voice in the patriarchal society. Draupadi always craved if she was a man. The society she lives never let her to gain knowledge, but she disciplined everything when the tutor teaches her brother Dhri. Once the tutor asked her, whether she is accompanying Dhri during the war. She has indifferent thoughts when compared to other women in her age, she neglects the necessity of war, and she asks how man find glory in war, when there are so many other ways to find it and she ratifies that she never allows her father and brother to do that. She know what she is and what she is capable of, but the circumstances never lead her to reach there even she is a princess. Almost all the men during that age married more allows one woman, but Draupadi questions that act and she wished to only one wife to her husband. Dhaima informs her that: "King always take other wives, men always break the promises they make before marriage Besides, if you are married off like Panchaal's other princess, you don't get a chance to her husband before he beds you." (30)

Royal family members especially the women are supposed to remain hidden from the gaze of sun. Draupadi makes fun of this by saying veil can help to hide both from sun and man. However, one day she went out wearing a veil to see the common people and this changed her mind about common people, a sense of respect arise in her towards the common people of Paanchaal. A sage once came to see her telling her future, she was surprised to hear that she will be married to five men. Even though, she is living in a society where polygamy exists, she cannot even think about polyandry, which means a woman having several husbands. She was happy in the Palace with Dhri, Krishna and Dhaima. Krishna, an avatar of Lord Vishnu was 
her close companion, who always saves her when she is in a trouble and a counsellor to many kingdoms. Sikhandi who is half woman and half man also inspired her life. Sikhandi is the elder daughter of king Draupada, Sikhandi was born as a woman not man, but she was raised as a man learning everything needed for warfare. The real situation of women during her age was:

They murmured gossip, chewed beetle leaf to redden their lips, exchanged recipes for live potions, pouted, giggled without reason and emitted suitable feminine shrieks if a bee orbited too close. From time to time, they tend me beseeching glances. If only I'd decide to go back inside the palace! This pitiless sun-even withal canopy, it was so bad for the skin! They'd have to spend hours soaked in yoghurt and turmeric paste to counter its ravages. (53)

Draupadi outlawed all kinds of luxuries and makeovers that ordinary woman do. She ignored them sternly and continued to read. She learned from the book about the complicated laws concerning household property, including servants and wives - caused her eyelids to droop. She doubted why men and women have separate duties to do, in the things both can do. She wished to create her own image. She has the intention to study everything that men and women can. For that she didn't care about others opinion. Also, she is very much concerned about finding an adequate partner. Her father bought the portraits of different emperors and she yearned for Krishna's presence to acknowledge about the good and evil of each emperor. She didn't want to be the wife of an old man, she prayed for the failure of the kings who came to see her, but each person who came there was anxious to hear her opinion. Among the portraits she got amazed by seeing Arjuna. But when she saw Duryodan and the companion with him, Draupadi no longer thought about Arjuna. She describes the companion as:

Older than the prince and austere-faced, the man sat upright, his lean body wary, as though he knew the world to be a dangerous place. Though in the midst of a 
court, he seemed utterly alone. His only ornaments were a pair of gold earrings and a curiously patterned gold armour, unlike anything $I^{`} d$ seen. His eyes were filled with an ancient sadness...Absurdly; I wanted to be the reason for his smile. (69)

The person whom Draupadi get attracted with is Karna, ruler of Anga and best friend of Duryodan. When Krishna roared against Karna, Draupadi felt distrustful by his word for the first time. Krishna asked her why she gets attracted to a chariot driver like Karna. She knows she cannot marry him, she dreamed for a married life, so she wants Arjuna to marry her, but more than Arjuna she loves Karna. She notices the danger of women in the history. She doesn't support Sita or Ghandhari, who had sacrificed their lives for their husbands. She questions what is the point of Ghandhari to tie her eyes if at all her husband is blind. All that Draupadi bloomed in her mind get faded. She became the wife of five people which she had never thought of. She was forced to deny all the dreams for her brother, in order to rescue him from death. This itself is the greatest example in the story that a powerful warrior itself is rescued by a woman.

Conclusion

The perfect woman concept is removed in the retold story of Mahabharata. Chitra Banerjee Divakaruni, by taking the life of Draupadi, tells the dreams, miseries and the expectations of a woman who opens the cage of perfection and flies against the traditional feminine concept. In that liberation, the protagonist finds her dreams and her identity. She finds solution richer questions without pausing for a male caretaker. In the original text of Mahabharata, there is no voice for Draupadi, but in this novel The Palace of Illusions, the voice of Draupadi can be heard, she finds herself possessing courage and enthusiasm to overcome any situation. She is portrayed in the novel, having a lot of imperfections. These imperfections show that there is no perfect woman image anywhere in the world, even in the Epics. She is the root cause of the Battle of Kurukshetra. This furthermore tells that nothing in the world is 
perfect and everyone is embarking for their own freedom or liberation. Even though Draupadi had grown up with all kinds of comforts from the palace she live, she never believed it as a felicity for her. She gave more prominence to her vision and to attain her own identity. She has never hidden her passionate feeling towards Karna, her husbands' staunching enemy from readers. It shows that she never put herself in a safe or advantageous position, to gain a perfect woman image. Till the end she rebels "against the boundaries the society has prescribed for women." (343) and returns to accompany her husbands on their final journey as "no woman had ever attempted it." (343). Validating the same desire for everlasting majestic glory, which rebounds in her and would be her "last victory over the other wives" (343). The foremost plight of Draupadi does not deviate from her husbands, all of them suffer from" the morass of depression" (321). The same despondency and grief that the war manifests in them. Her life was already predicted by the sage, but she wants it to be unpredictable. She wished to create her destiny, also she dreamed to create her own palace, where she can easily express her identity, which she could not express in her father's palace. She recognizes her father's palace with a prison-house, which tries to deter her growth as an individual. This from the patriarchal chains, the woman Draupadi is unlocking the concept of liberation. 


\section{Works Cited}

Chitra Banerjee Divakaruni. The Palace of Illusions. New York: Picador, 2008.

Sudipta Guota. "I shall tell you all: Draupadi as the protagonist of the epic in Chitra banshee Divakaruni's The Palace of Illusions”. Postscriptum: An interdisciplinary journal of literary studies [online], 1.2. Pp 52-60, Jul. 2016.

Variar, Akhila \& Dr. Abhisarika Prajapati. "Myth and Modernity in Chitra Banerjee Diavakaruni's The Palace of Illusions.” JOELL (Veda's Journal of English Language and Literature. [online] 5.1 (2018). pp 304-307. 